\title{
原綿の開繊に関する研究
}

（第 5 報）最近のベールオープナが紡績中間製品の品質に与える影響

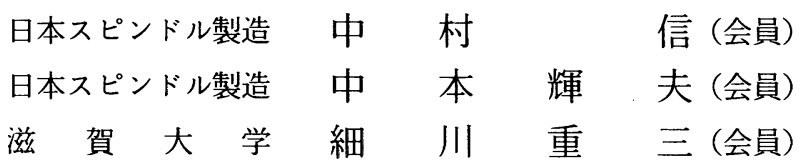

\section{Study of Bale Opening \\ Part 5: Effect of New Bale Opener on Quality of Intermediate Products in Spinning Process}

\author{
Makoto Nakamura*, Teruo Nakamoto* and Juzo Hosokawa** \\ ${ }^{*}$ Nihon Spindle Mfg. Co., Ltd, Shioe Amagasaki, Hyogo \\ ${ }^{* *}$ Shiga University, Hiratsu, Shiga
}

\begin{abstract}
Finer and more uniform tuft is opened by use of the latest new bale opener in comparison with those currently in use. What effects this finding have on quality of intermediates in spinning process such as laps, slivers and spinning yarn, for instance, have been examined.

As results of the examination, it was found that laps are slivers having a small coefficient of variation of grain, that is, homogeneous laps and slivers of less variability, and obtained, and moreover, it was also found that spinning yarn of good quality is got with less yarn breakages in spinning process.

(Received March 30, 1991)

摘 要

最近の新しいベールオープナを用いることにより，従来に比較して，綿塊は細かく均一な夕フトに開瀻される，このことが, 紡績工程の中間製品一例えば, ラップ, スライバ, 精紡糸など一の品質に, どのような影響を与えるかについて検討した。

この結果，ゲレン変動率の小さい，すなわち，ばらつきの少ない均斉なラップ，スライバが得られること．また，精紡工程に おいても糸切れが少なく，品質のよい糸が得られることが分かった。
\end{abstract}

(平成 3 年 3 月 30 日受理)

\section{1. 緒 言}

最近, 原綿に関して混打綿工程の初期の段階で, できるだけ細かく均一に開繊し，除塵，混綿を容易， かつ速やかに行う考え方が定着しつつある.

この考え方に基づき,これまで開繊夕フトの構 造，開繊条件とタフトの大きさとの関係およびタフ トの大きさと混合状態の関係などについて報告し
$た^{1,2,3)}$

本報告では，実際に細かく均一な夕フトの開繊を 可能にした最近の新しいベールオープナが紡績工程 中間製品の品質によ゙のような影響を与えるかについ て検討を行った.

\section{2. 検討方法}

最近の新しいベールオープナによる開繊夕フトの 
大きさへの影響についてはすでに報告しだ゙。 ここ では，この新しいベールオープナ（以下，新型 BO と呼ぶ）を通して作られた開繊綿および従来より長 年用いられてきたベールオープナ（以下，従来型 BO と呼ぶ）を通して作られた開繊綿を混打綿工程 に供給し, 次の工程に通して出来た紡績各工程中間 製品の品質を順次比較, 検討して新型 $\mathrm{BO}$ の性能を 評価した。

新型 $\mathrm{BO}$ および従来型 $\mathrm{BO}$ の構造の差異につい て，その概略図を図 1 に示す．以下の結果はいずれ も国内の紡績 5 社 7 工場での操業によるものである ため, 新型 $\mathrm{BO}$, 従来型 $\mathrm{BO}$ の操業条件とも個々に 少しずつ異なっている，本報では，上記 7 工場にお ける測定結果をそれぞれ報告する。これら測定デー 夕を採集した工場は，図番号と工場記号 $(A \sim G)$ の 対比表を表 1 に示したので参照願いたい.

また, 各工程での中間製品の品質は下記の 3 項目 を比較した。

4) 混打綿工程におけるラップの均斉度，2）梳綿, 精梳綿, 練条工程におけるスライバの均斉度 (重量, グレン変動率など）および，３）精紡工程での系切 れおよび糸の品質への影響, の 3 つである。これら の測定方法は表 2 に示した.

\section{3. 検討結果}

\section{1 ラップの品質への影響}

ラップは開繊された綿と，最も近い紡績工程中間 製品であるため, ベールオープナの影響を最も顕著 に示すと考えられる.

図 2 には, ベールオープナによって開繊された夕 フトの大きさがラップの重量変動率に与える影響を 示した 1 つの例を示す.タフトの大きさの平均值は

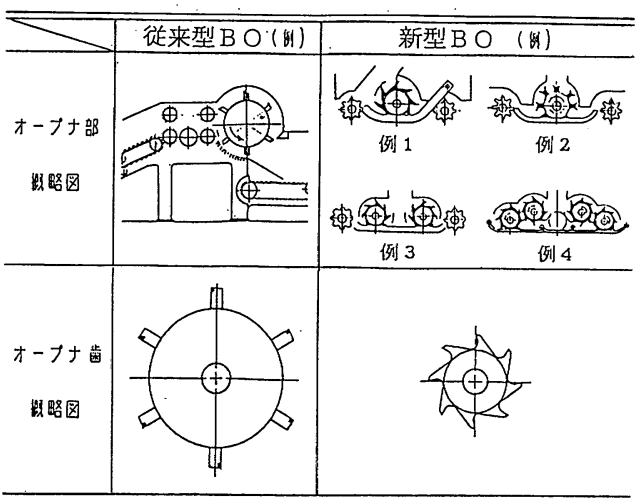

図 1 ベールオープナの開繊部の比較

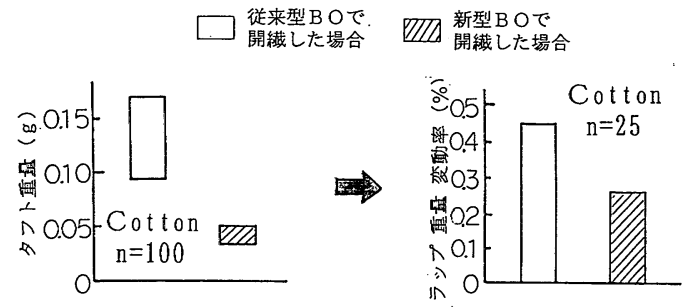

図 2 綿タフトの大きさ（重量）とその変動が ラップの均整度 (重量変動率) に与える影響

$130 \mathrm{mg}$ (従来型 $\mathrm{BO}$ ) 加ら $40 \mathrm{mg}$ (新型 $\mathrm{BO}$ ) と約 1 / 3 になり, 重量のばらつき幅む $80 \mathrm{mg}$ から $20 \mathrm{mg}$ へと約 $1 / 4$ になっている. また， ラップの重量変 動率は 4.6\%（従来型 BO） から 2.6\%（新型 BO）と $2 \%$ 小さくなっている.このことから, 新型 BO で 開緎したタフトは，重量およびばらつき幅ともに小 さく，これらが混打綿工程に供給されると，混りや すく，均斉なラップに形成されると考えられる.

このほか, ラップ 1 本ごとの重量変動率への影響 を示した 2 つ例を図 3 の（a）（b）に示す.これら

表 1 本報告の図番号と工場記号の対比

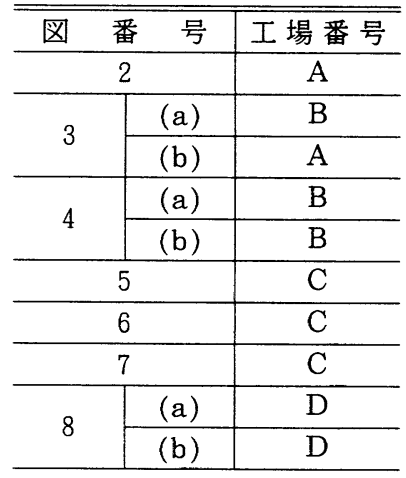

\begin{tabular}{|c|c|c|}
\hline 図 & 号 & 工場番号 \\
\hline \multirow{2}{*}{9} & (a) & $\mathrm{A}$ \\
\hline & (b) & $\mathrm{B}$ \\
\hline \multirow{3}{*}{10} & (a) & $\mathrm{A}$ \\
\hline & (b) & $\mathrm{B}$ \\
\hline & (c) & $\mathrm{C}$ \\
\hline \multicolumn{2}{|c|}{11} & $\mathrm{E}$ \\
\hline \multirow{2}{*}{12} & (a) & $\mathrm{F}$ \\
\hline & (b) & G \\
\hline \multirow{2}{*}{13} & (a) & $\mathrm{B}$ \\
\hline & (b) & $\mathrm{E}$ \\
\hline
\end{tabular}


表 2 紡績中間製品の品質評価項目とその測定方法

\begin{tabular}{|c|c|}
\hline 品質評価項目 & 測定方 \\
\hline $\begin{array}{l}\text { タフトの大きさ } \\
(\text { タフト重量 : g g) }\end{array}$ & 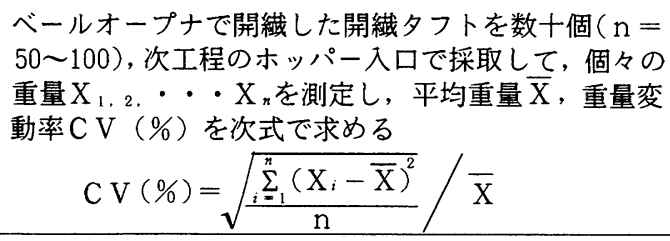 \\
\hline $\begin{array}{l}\text { ラップの均斉度 } \quad(1) \\
\text { (ラップ重量の変動率 : \% ) }\end{array}$ & $\begin{array}{l}\text { ラップの一定位置より, 一定長さ（例 : } \ell=1, \\
5,10 \mathrm{yd}) \text { 数〜数十個採取し, 順次, 重量を測定し, } \\
\text { その重量変動率 C V } \mathrm{V} \text { (\%) を求める（求め方は上記と } \\
\text { 同じ） }\end{array}$ \\
\hline $\begin{array}{l}\text { ラップの均斉度 （2） } \\
\text { (ラップ重量の変動率 : \% ) }\end{array}$ & $\begin{array}{l}\text { ラップ } 1 \text { 本分ごとの重量を数十本（例 } \mathrm{n}=10 \text { ～50） } \\
\text { 測定し，その重量変動率 C V (\%) を求める（求め方 } \\
\text { は上記と同じ） }\end{array}$ \\
\hline $\begin{array}{r}\text { ラップの量目合格率 } \\
(\%)\end{array}$ & $\begin{array}{l}\text { 全測定ラップ本数に対する, 目標設定範囲内にある } \\
\text { ラップ本数の割合を求める }\end{array}$ \\
\hline $\begin{array}{l}\text { スライバの均斉度 } \\
\text { (スライバゲレン変動率 : \%) }\end{array}$ & 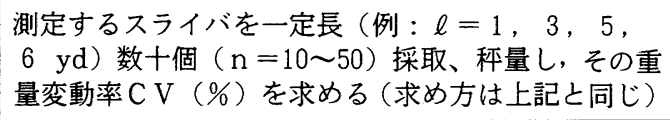 \\
\hline $\begin{array}{l}\text { 糸切れ数 } \\
\text { (本数 } / 400 \text { 鍾・時間) }\end{array}$ & $\begin{array}{l}\text { リング精紡機 } 1 \text { 台 }(400 \text { 錘 }), \quad 1 \text { 時間当たりの糸切れ } \\
\text { 本数の測定を数ドッフィング行い, その平均値を求 } \\
\text { める }\end{array}$ \\
\hline
\end{tabular}

※ 上記の試料数や試行回数等は各紡績工場によって異なるため, その値 についてはデータ中に分かる範囲で示した。

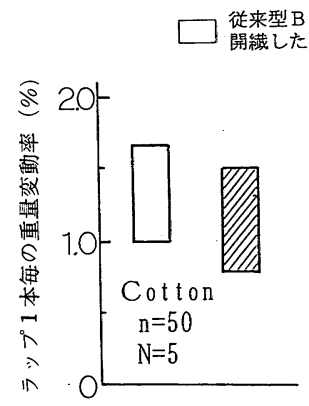

(a)

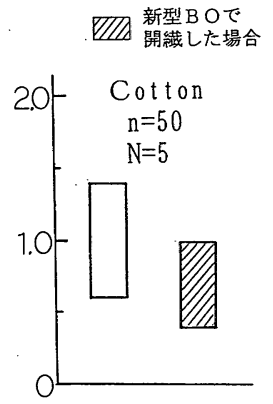

(b)
図 3 ラップ 1 本ごとの重量変動率の比較

は，いずれも試料数は 50 個 $(\mathrm{n}=50)$, 試行 (測定) 回数は 5 回 $(\mathrm{N}=5)$ であり,この場合, 変動率の平 均値は新型 $\mathrm{BO}$ 通しの方が $0.2 \sim 0.5 \%$ 小さい值と なっている.

次に, ラップの量目合格率に与える影響につい て, 2 つ例を図 4（a）（b）に示す.（a）の場合は 合格率の平均が $93 \%$ から $98 \%$ に, また（b）の場合 は $92 \%$ から $96 \%$ に向上している. 以上の結果は, 新型 BO で開繊したタフトの大きさが細かく均一で

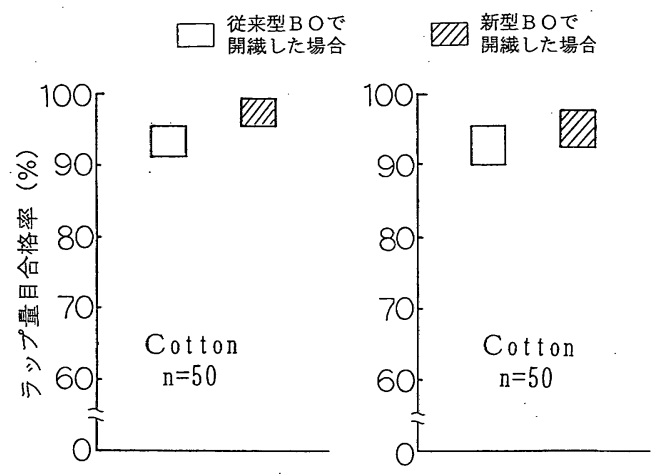

(a) (b)

図 4 ラップ量目合格率の比較

あるために，混打綿工程のラップ形成にも影響を及 ぼし， 1 本ごとの重量の変動の少ない，均質なラッ プが作られたことを示している.

\section{2 スライバ品質への影響}

\subsection{1 カードスライバのゲレン変動への影響}

新型 $\mathrm{BO}$ で細かく均一なタフトが開繊され，混打 
綿工程で混ぜ合わされることにより，スライバゲレ ンによ゙のような影響を与えるかについて，図 5 に示 す.（a）は従来型 $\mathrm{BO}$ で開繊して得たラップを $\mathrm{A}_{1}$ から $\mathrm{A}_{5}$ の 5 台のカードに供給した場合のもので, 6 ヤード当たりの綿スライバの重量を連続50個測定 した結果を示し，（b）は，時間差をおいて同様に， 新型 $\mathrm{BO}$ によるラップを上記と同じカードに供給し た場合の結果である.

新型 $\mathrm{BO}$ を通り紡出されたスライバでは，大きな 変動むらが無くなることが分かる. また，この 5 台 のカードにおけるスライバゲレン変動率を比較した 結果を図 6 に示す.上記 5 台のカードの平均值で $4.4 \%$ から $3.2 \%$ へと $1.2 \%$ ほど隇少しており，スラ イバ太さむらが大幅に改良されていることが分か る.

同様に，ポリエステル緘維のスライバゲレンにお ける変動率について， $\mathrm{B}_{1}$ から $\mathrm{B}_{10}$ の10台のカードで 試験した結果を図 7 (a)（b）に示す。ポリエステル 繊維の場合についても, カード10台の平均値で, $3.6 \%$ から $2.7 \%$ へと大きく減少し, スライバむらが かなり改良されていることが分かる.
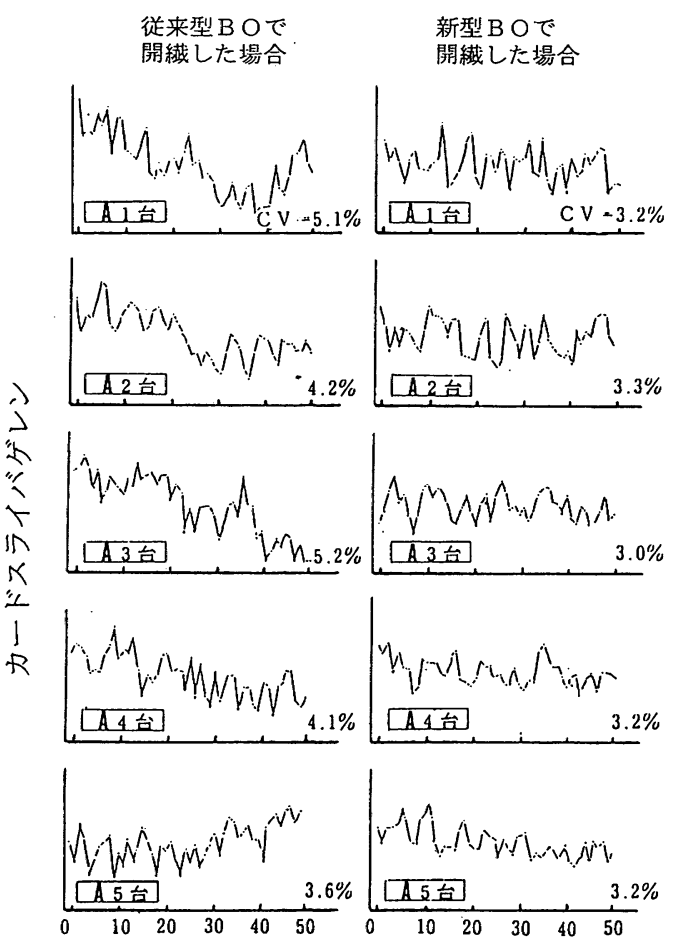

(a)

試料番号

(b)

図 5 カードスライバゲレン変動状態の比較

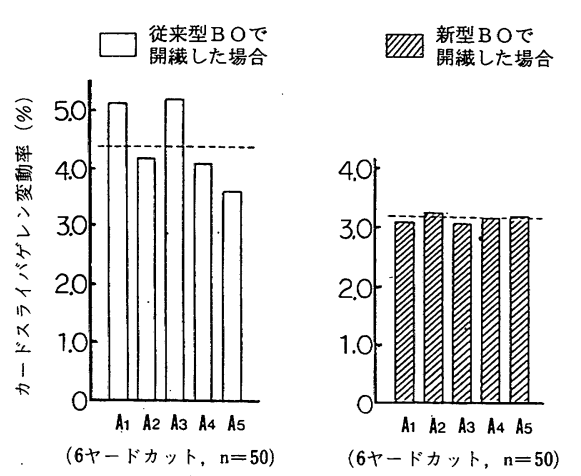

図 6 カードスライバゲレン変動率の比較 (綿の場合)

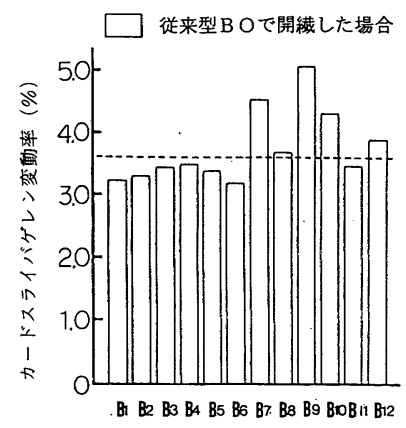

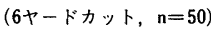

ツ10 新 型BOで開絾した場合

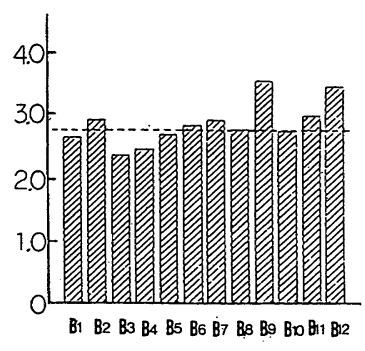

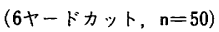

図 7 カードスライバゲレン変動率の比較 （ポリエステル織維の場合）

次に，上記とは別の 2 つの紡績工場における比較 結果を図 8 （a）（b）に示す.（a）は綿 40 ss 紡出用, （b）は綿 $30^{\text {s }}$ 紡出用スライバの $\mathrm{n}=100, \mathrm{~N}=5$ にお けるゲレン変動率を比較したものである.（a）の場 合, 変動率の平均值で $0.2 \sim 0.3 \%$ (b) の場合 0.6 $0.7 \%$ 小さくなり，スライバの太さむらが減少する ことを示している.

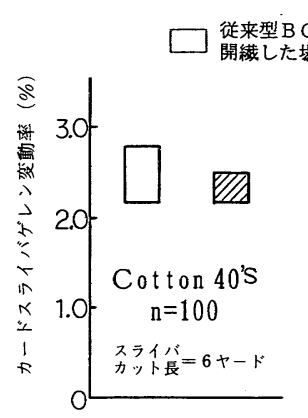

(a)

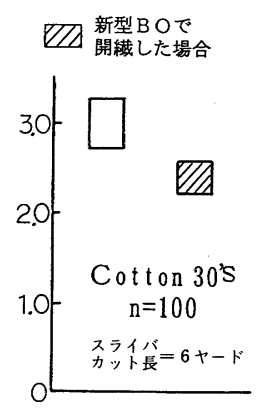

(b)
図 8 カードスライバゲレン変動率の比較 


\subsection{2 コーマスライバのゲレン変動率への影響}

次に, コーマスライバのゲレン変動率への影響に ついて，2つの紡績工場における比較例を図 9 (a) (b) に示す

(a)，（b）とも $\mathrm{N}=5 \sim 10$ 回測定した際の変動率を 示したものである. それぞれ変動率の平均値で $2 \%$ から 1.2\%，1.7\% から 1.3\% となり，はっきりした 効果が出ていることが分かる.

\subsection{3練条スライバゲレン変動率への影響}

練条スライバの品質には，カード工程におけるむ ら自動制御装置（オートレベラ）および練条工程に おけるダブリンやレベラの効果が大きく影響するも のと考えられる。しかし，ここではこれらの影響を 考慮に入れずに，単純に比較した 3 つの工場におけ る事例を図10 (a) (b) (c) に示す.いずれの場合も, 変動率の平均值の差は $0.2 \sim 0.3 \%$ であり, やはり, 新型 $\mathrm{BO}$ で開繊し，大きさ，均一さともにそろった タフトの場合，均斉な練条スライバが得られること が分かる。

\section{3 精紡糸の糸切れへの影響}

以上により，開繊タフトが細かく均一になり，そ 従来型BOで開瀻した場合 Ø新 型BOで開緎した場合

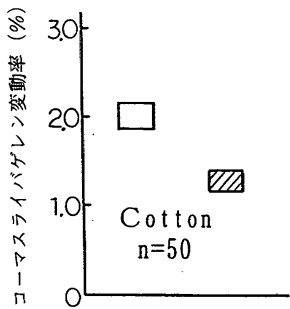

(a)

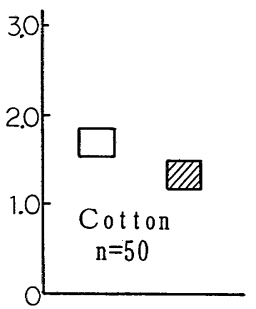

(b)
図 9 コーマスライバゲレン変動率の比較 (スライバカット長 $=6$ ヤード)
れらが均等に混合されると，カードスライバ，コー マスライバ，練条スライバに対して良好な結果を与 えることが分かった。

これらの結果がこの後の粗紡，精紡工程などに与 える影響を実際の操業をしながら確認することは, 多くの紡績条件や機械条件および性能が関係するた めに, 著しく困難である. しかしながら，精紡工程 の糸切れに対して，原綿の開繊状態は何らかの形で 影響を及ぼしていると考えられる。図11には従来型 $\mathrm{BO}$ と新型 $\mathrm{BO}$ で開縺された綿が時間を置いて同一 工程を通り，最終的に同じ精紡機（10台）によって, 紡出した際の糸切れ試験結果を示す。すなわち，同

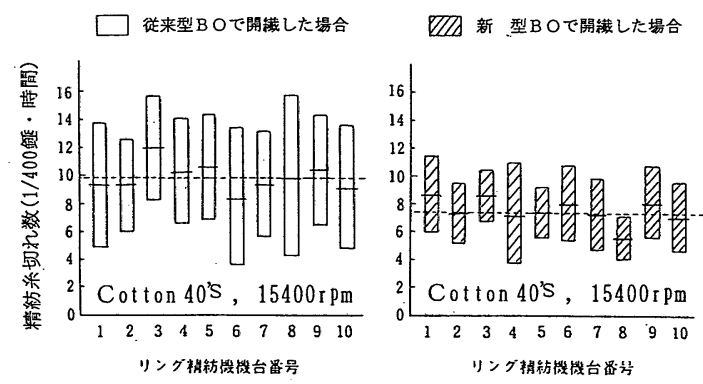

図11 精紡系切れ数（1／400 鍾・時間）の比較

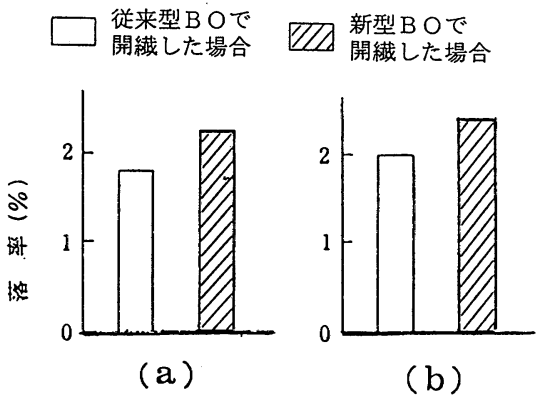

図12 混打綿機の除塵工程間 （SC〜DO）の落率

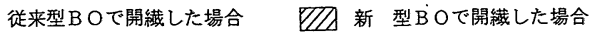

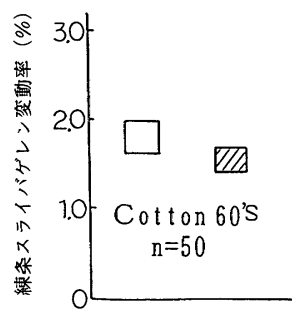

(a)

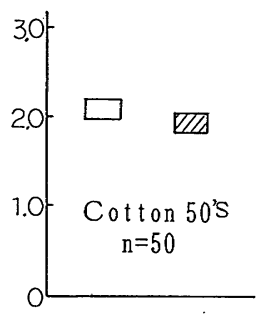

(b)

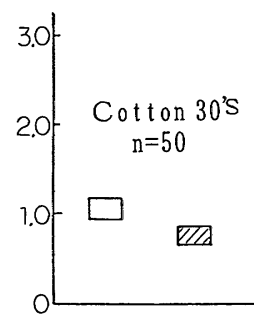

(c)

困10 練条スライバゲレン変動率の比較 


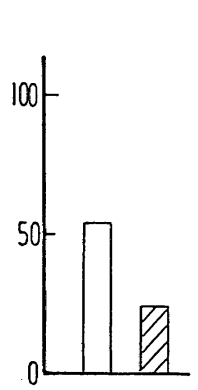

TH I N

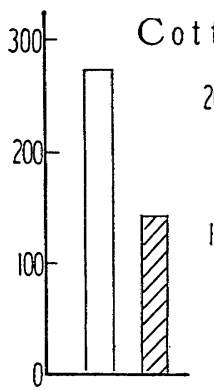

TH I CK

(a)

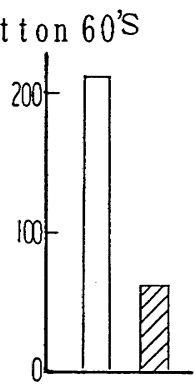

NEPS

図13 IPI 値測定結果

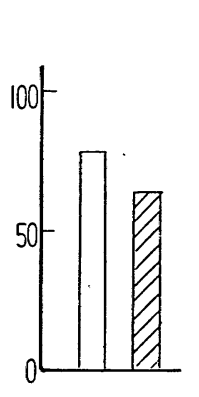

TH I N

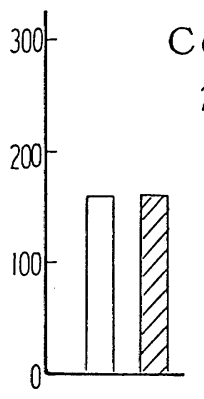

TH I CK

(b)
Cotton 50's

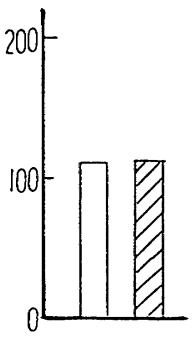

NEP S 一なタフトを開繊し，混打綿工程以下の工程に供給 すると，各工程で得られる中間製品の品質に良好な 影響を与えることが分かった。

すなわち, 従来型のベールオープナで開繊した場 合に比べて最近の新しいベールオープンで開繊した 場合, 以下の 3 つの特長を示すことが分かった。

1 ）混打綿工程では, 重量変動率において, 例えば 0.2 〜 0.5\% 少ないラップが得られること.ま た，ラップの量目合格率も増加すること。

2）梳綿工程, 精梳工程, 練条工程においてはスラ イバゲレン変動率が, 例えばカードスライバで $3 \%$ から 2.3\%, コーマスライバで $2 \%$ から $1.3 \%$ へと, 小さな值を示し, 均斉なスライバが 得られること.

3）精紡工程では系切れが少なく, 機台間, 機台内 における変動も少なくなり，IPI 試験において も THIN, THICK, NEPS とも良好な結果が得 られること.

以上, 紡績の各工程を経るごとに, 工程ごとの機械 特性などいろいろな要因が含まれてくるために，デ 一夕間の比較は困難であるが, ある一定の傾向が得 られたものと考えられる.

\section{参考文献}

1）細川, 中村 ; 織機誌, 41, P 349 (1988)

2) 中村, 細川 ; 繊機誌, 41, P 385 (1988)

3）中村, 笹倉, 細川; 繊機誌, 44, T 88 (1991)

4) 中村, 有満, 細川; 絨機誌, 77, T 111 (1991)

最近の新しいベールオープナを用いて, 細かく均 